\title{
Chitosan Nanoparticles for Generating Novel Systems for Better Applications: A Review
}

Yashwanth Radhakrishnan, Ganesh Gopal, Chittur C Lakshmanan and Krishna S Nandakumar

Department of Biosciences, ITC Life Science \& Technology Centre (LSTC), India

*Corresponding author: Nandakumar KS, Department of Biosciences, ITC Life Sciences \& Technology Centre (ITC LSTC), \# 3, 1st Main, Peenya Industrial Area, Phase 1, Bangalore-560058, India, Tel: +91 80427874 50; Fax: +91 80427875 07; E-mail: Nandakumar.ks@itc.in

Received date: June 25, 2015; Accepted date: July 31, 2015; Published date: August 07, 2015

Copyright: (c) 2015 Radhakrishnan Y, et al. This is an open-access article distributed under the terms of the Creative Commons Attribution License, which permits unrestricted use, distribution, and reproduction in any medium, provided the original author and source are credited.

\begin{abstract}
The environmental sustainability and use of environmentally acceptable biomaterials are major areas of scientific and industrial research. In recent times, identification and application of suitable biopolymers instead of petroleum derived conventional polymers are gaining more attention. Chitosan and chitosan derived nanoparticles and nanocomposites are very promising due to their versatile properties and have found applications in various areas such as biomedical, foods, food packaging and personal care. Many studies suggest that chitosan nanoparticles and their derivatives are one of the best barrier and film coating materials for preserving the quality of foods and for delivering skin care products, mainly due to their biodegradability and anti-microbial properties. The present review gives insight on the progress made in the application of chitosan nanoparticles specifically in foods and food packaging, personal care products and in biomedical industry. Future studies shall address establishment of industrial scale up of chitosan nanoparticles, safety and quality aspects of these chitosan derived products for human use.
\end{abstract}

Keywords: Chitosan; Chitosan nanoparticles; Chitosan composites; Food packaging; Dietary fiber; Wound healing; Gene delivery

\section{Introduction}

Chitin is the second most abundant natural biopolyaminosaccharide polymer, next to cellulose. The exoskeleton of crustaceans, shell mollusks and to certain extent a few species of fungal cell wall contain chitin and chitosan. Chemically, chitosan is deacetylated derivative of chitin. The greatest advantage of chitin and chitosan are they are biodegradable, non-toxic and less antigenic nature [1]. Based on several studies chitin is converted into chitosan and the key four steps involved in the process are deproteinization, demineralization, decoloration and deacetylation [2]. Nanotechnology can produce variety of new materials which may have wide functional purposes. The major advantage of nanoparticles is that it provides more surface area and enhanced functional properties. Chitosan and chitosan particles are used to make a wide variety of compositions containing chitosan nanomaterials, nanofibers, films, nanoclay, colloids, composites, gels and other products either alone, in combination with other natural chemical or biological or biochemical compounds $[3,4]$. The physical properties of chitosan nanoparticles depend on concentration of chitosan used, amount of cross linking and molecular weight of the chitosan. Many methods have been used to prepare chitosan nanoparticles such as ionic gelation method using acetic acid and sodium tripolyphosphate [5]; desolvation method using sodium sulphate and acetone, spray drying and covalent cross linking [6-8].

Chitosan and chitosan nanomaterials have a wide array of applications in biomedical, pharmaceutical, nutraceutical, foods and personal care areas [9-11]. In health care industry, chitosan and chitosan materials are used as antimicrobial, antitumor, antiulcer, antidiabetic and cholesterol lowering agent. In the areas of food, food packaging and personal care, the antioxidative property, film forming capability, antimicrobial effect, clarifying effect, gelling nature, additive property, color stabilizing effect, anti-inflammatory and fiber like property of chitosan and chitosan derivatives make them an excellent choice [12-15]. In biomedical and pharmaceutical areas, chitosan nanomaterials play a pivotal role in delivery of genes and molecules, encapsulation, bioavailability enhancement, oral delivery of growth factors, insulin and optimal drug delivery [16-18]. Considering the importance of safety, quality, efficacy and environmental sustainability, the application of chitosan derived materials seem expanding as evidenced by rapid increase in publications, number of patents and products. Hence, in the present manuscript, we have attempted to review the current scientific developments in chitosan nanoparticles and their applications mainly in foods, personal care, and food packaging and also in other areas of applied biology and pharmaceutical sciences.

\section{Chitosan in Foods}

Application of chitosan in foods is gaining interest, specifically after the chitosan derived from shrimp has been recognized as Generally Recognized as Safe (GRAS) for common use in foods by the US Food and Drug Administration in 2011. The role of chitosan particles in foods could be viewed in broad categories based on their functions such as i) Antimicrobial property, ii) Additive property that includes functions such as color stabilization, emulsification, antioxidant activity and iii) Dietary fiber like property aiding water holding and fat entrapment, thereby imparting health benefit. Due to the multifunctional properties of chitosan, in the last decade the number of patents issued on the processing of chitosan and its derivatives related to the use in food industry has increased [15]. 
Page 2 of 10

\section{Antimicrobial property}

Antimicrobial function of chitosan is known against wide variety of Gram-positive, Gram-negative bacteria, mould and yeast. The polycationic property of chitosan exhibits antimicrobial activity due to its ability to interact with negatively charged cell membranes of these microbes [19]. Both Gram positive and Gram negative bacteria have been found to be affected by chitosan having a minimum inhibitory concentration (MIC) in the range of 100 to $2000 \mathrm{ppm}$. The variations in the MIC values even for the same species across studies may be due to varying degree of acetylation of chitosan, since acetylation is associated with antimicrobial effect. Similarly, micro and nano chitosan particles have been found to show antifungal activities with MIC values ranging from 10-500 ppm against variety of species. Fungal species such as Botrytis cinerea and Drechstera sorokiana exhibited very low MIC of $10 \mathrm{ppm}$ while several other fungi such as Candida albicans, Microsporum canis, Aspergillus fumigatus, Aspergillus parasiticus have shown higher MIC between 1000 and 2000 ppm, while for Trichophyton mentagrophytes and Byssochlamys spp. the MIC values were found about 2000-5000 ppm [19]. In addition to the concentration of nanoparticle, size and zeta potential of both low and high molecular weight chitosan tend to influence the inhibitory effect against $C$. albicans and $F$. solani. However, only high molecular weight chitosan solution and nanoparticles were able to inhibit the growth of $A$. niger [20].

Three mechanisms have been put forwarded to explain the antimicrobial activity of chitosan: i) the positively charged chitosan and the negatively charged bacterial cell membrane, enhancing the membrane permeability [21]; ii) penetrating power of chitosan in to the nuclei of the microorganism leading to the inhibition of mRNA and protein synthesis; and iii) the chelating ability thereby creating an external barrier leading to essential nutrients suppression [19,22]. In general, it was observed that lower the molecular weight and the degree of acetylation, the higher would be the effectiveness of chitosan in reducing the growth and multiplication of microorganisms. Previous reports suggest that antimicrobial activity of chitosan is modulated by acidic conditions and this may be due to the loss of positive charges on the amino group at neutral $\mathrm{pH}$ and hence antimicrobial activity of chitosan may be decreased at neutral $\mathrm{pH}$ [23].

Several studies have focused on the antimicrobial action of the chitosan micro particles on pathogenic organisms, but little is known about the antimicrobial potential of chitosan and chitosan nanoparticles against food spoiling microorganisms. Yeast was completely eliminated following the addition of $0.3 \mathrm{~g}$ of chitosan per liter of pasteurized apple-elder flower juice stored at $7^{\circ} \mathrm{C}$. The total count and more specifically the lactic acid bacterial counts increased at a slower rate. However, the increase of bacterial count was relatively lower as compared to the increase in the control [24]. Chitosan has been used as a clarifying agent in several juices including orange, pomegranate, apple and others. Earlier, use of chitosan in the treatment of fruit juices showed inhibition of yeast but failed to inhibit E. coli $\mathrm{O} 157: \mathrm{H} 7$ suggesting that it may increase the food poisoning risk [25]. However, Abd and Niamah showed chitosan at a concentration of 0.2 to $1 \mathrm{~g} / \mathrm{L}$ in apple juice could inhibit growth of some spoilage bacteria, mould and yeast [26]. Recent developments in the area of chitosan admixtures, especially arginine-functionalized chitosan showed antibacterial activity against E.coli $\mathrm{O} 157$ in chicken juice [27].

Earlier we had indicated liposomes and chitosan derived materials could be better delivery agents for novel vaccines [28]. Furthermore, our collaborator's work towards understanding the efficacy of
Chitosan-dextran sulphate (CD) nanocapsules in delivering specific drugs against intracellular bacterial pathogens suggest that $\mathrm{CD}$ nanocapsules could effectively deliver specific antibiotics against intraphagosomal Salmonella leading to killing and clearing the pathogen [29]. These above findings along with other available evidences suggest that chitosan and chitosan derivatives seem to possess significant antimicrobial activity and potential drug delivering system.

\section{Additive property}

Food additives are integral component of any packaged food available today and are under regulatory guidelines. A plethora of additives are used primarily to preserve, blend, thicken and color food. Considering the wide variety of functional properties of chitosan and due to its natural source, chitosan in various forms and combination are one of the best known food additives. The importance of chitosan as food additive could be highlighted by the fact that about three decades back Japan and Korea have approved chitosan as a food additive [12]. Low molecular mass chitosan and chitosan oligosaccharides have been used generally as food additive and are suggested to have enhanced efficacy especially in acidic food products irrespective of the size and acetylation status of chitosan [30]. It is pertinent to note that chitosan acts as thickening agent and increases the viscosity of food without any allergic or toxic effect, due to its natural origin [12]. Chitin and chitosan have been shown to support stability on food emulsions. Also, microcrystalline chitin as additive distributes evenly and enhances flavour and taste of food by forming pyrazines during normal cooking temperatures with characteristic roasted taste and aroma [31].

\section{Color stabilization}

Chitosan binds to many classes of dyes such as disperse, acid, sulphur, reactive and others with high affinity due to the molecular structure and also the rate of diffusion of color appears similar in both cellulose and chitosan [12,32]. The influence of packaging made of chitosan on color stability in refrigerated ground beef has been studied previously [33]. Also, in fresh ground beef patties, chitosan in combination with rosemary extract showed synergistic effect resulting in the most intense red color stabilization and anti-oxidative protection [34]. Similarly, chitosan based edible films and packaging of fresh cut fruits and vegetables have been implicated strongly in color stabilization and retention, extending shelf life. However, one of the main limitations of their application is in oligosaccharide engineering due to difficulty to produce the specific glycosidic structures [30].

\section{Antioxidant activity}

Several studies have previously reported antioxidative properties of chitosan especially in food products that contain high amounts of unsaturated fatty acids which are sensitive to oxidation during storage $[35,36]$. Chitosan scavenges free radicals or chelate metal ions from the donation of a hydrogen or the lone pairs of electrons and this is considered responsible for the antioxidant ability and free radical scavenging activity of chitosan [37]. In addition, the low molecular weight of chitosan and the degree of quarternization appear to contribute to the antioxidant capacity of chitosan [38]. Addition of other naturally occurring phenolic antioxidant such as carvacrol or polyphenolic compounds with chitosan has been suggested to have synergistic effect as mutual prodrugs [38,39]. Low molecular weight chitosan oligomers and nanoparticles have been shown to have 
Page 3 of 10

significantly higher antioxidant activity when compared to higher molecular weight chitosan oligomers [40].

\section{Dietary fiber and health benefits}

Use of chitosan as a dietary fiber is one of the promising applications of chitroan in foods. Albeit chitosan does not exhibit classical properties of fiber, the high water binding nature, upper intestinal tract non digestibility and being a biopolymer supports chitosan with dietary fiber-like properties. However, the chemical form and the polymerization degree determine the efficacy of chitosan through oral administration. Solubility of chitosan is promoted in the acidic environment of the stomach and this allows chitosan to bind to fatty acids and lipids and it is proposed that greater portion of such lipids bound to chitosan is known to be excreted rather absorbed [41]. Several patented formulation of chitosan with other fibers in the form of tablets, capsules and drinkables are available as nutritional supplement [12]. The chitosan fibers have been implicated in management of body weight [42] and in lowering lipid levels [43].

Chitosan as a dietary fiber has been proposed to play important roles in fat entrapment, glucose dialysis and water holding capacity [12]. Further these authors concluded that chitosan acts similar to soluble fiber albeit the mechanism between vegetable soluble dietary fiber and chitosan might be different. Methods to determine the chitosan levels in foods seem to differ substantially and also the amount of detected chitosan depends on the presence of reducing sugars in the food, since Maillard reaction might happen between the chitosan and reducing sugar [12].

The beneficial effect of chitosan and chitosan derivatives in prevention and treatment of age-related dysfunctions especially in elderly such as diabetes mellitus, hypercholesterolemia, atherosclerosis, cardiovascular diseases, neurodegenerative diseases, and cancer has been reviewed earlier [44]. Liu et al. showed that in Streptozotocin treated rats which were fed with low and high molecular weight chitosan there was a significant decrease in liver gluconeogenesis and increase in skeletal muscle glucose uptake suggesting the potential effect of chitosan in alleviating diabetic hyperglycemia [45].

The role of chitosan in the areas of cardiovascular health and weight management is relatively less explored. Orally administered chitosan about 1.2 grams per day for 8 weeks mildly reduced hypercholesterolemia i.e. reduction of total and LDL cholesterol, one of the important risk factors in cardiovascular diseases [46]. The use of chitosan as nutraceutical product in maintaining cardiovascular health by regulating lipid profile and having benefit on anthropometric profile is reviewed recently [44,47]. Furthermore, studies carried out in rats fed with high cholesterol suggest that chitosan may exert effect on fecal bacterial enzyme functions, change the level of short-chair fatty acid concentrations and extend beneficial effect to the distal colon in rats [48]. Also, evidence suggests that the microbiota of the caecum in the rats supplemented with copper loaded chitosan nanoparticles changed beneficially [49]. Taken together, these findings on the dietary fiber like properties of chitosan and the ability of chitosan to bind to lipids provide compelling evidences to hypothesize that chitosan induced body weight reduction may be attributed to the alteration of the intestinal microbiota. However, detailed randomized clinical studies to delineate the effect of chitosan formulation in weight reduction need to be conducted.

\section{Chitosan in Gene Delivery}

Gene delivery has a great potential in treatment of many diseases by introducing the genetic materials into the living systems [50]. Modified forms of chitosans like O-alkylated chitosan, has been used in delivering genetic materials [51]. Chitosan has primary amine groups and these repeating groups become protonated in acidic conditions. Chitosan derivatives have better solubility and buffering capacities [52]. This property of chitosan derivatives has efficiently been used to transfect different types of cells lines for delivering genes. Chitosan alone may have lower transfection efficiency and to increase the efficiency, Oliveira and colleagues studied diethylethylamine chitosan derivatives which resulted in condensation of DNA [17]. Lu et al. observed that the transfection efficiency of chitosan-graftpolyethylenimine DNA was similar to that of Lipofectamine 2000 in chondrocytes and synoviocytes without affecting cell viability [53]. Due to low cytotoxicity, the authors have suggested that chitosan might be a safe and efficient vector for gene delivery in chondryocytes and synoviocytes. It is thought that chitosan and polyethylenimine complexes protect the DNA from serum degradation [54]. Previous study has demonstrated quaternized oligomers to be efficient than oligomeric chitosans and the size of the complexes ranged from 200-500 $\mathrm{nm}$ [55]. However, it was reported that release of DNA from chitosan could be changed by formulation conditions [18] $\mathrm{Li}$ and Birchall tested cationic polymer chitosan for dispersability and reported higher deposition of chitosan on modified lactose formulation [56].

Various cells have been shown to have varying transfection efficiencies and studies have shown that HEK293 cells tend to take chitosan DNA micro particles more efficiently than HeLa and 3T3 cell lines [57]. In addition to increase in the levels of expression of reporter gene, DNA uptake was found different among various cell lines. It was also observed that degree of deacylation and molecular weight of chitosan play an important role in expression of genes [16]. The ratio of combinations modulated the expression levels and was attributed to electrostatic binding and particle stability [58].

In addition to the conventional methods of gene delivery, novel systems such as magnetic nanoparticles coated with chitosan and chitosan nanobubbles have also been studied. The spherical ferriferous oxide complexes were found to have significant effect on controlled release of DNA [18]. Others have shown that DNA loaded chitosan nanobubble shells with a diameter of about $300 \mathrm{~nm}$ with positive charge as a system for delivery of DNA and found efficiency in delivering genetic materials without affecting cell viability [59].

The storage stability of chitosan nanoparticles at various temperatures have also been examined by earlier workers [60]. In a series of studies, Mohammadi et al. showed Fibronectin Attachment Protein of Mycobacterium bovis (FAP-B) ligand was added to chitosan nanoparticles to form chitosan-DNA-FAP-B nanoparticles via electrostatic attraction [61]. Chitosan-DNA-FAP-B nanoparticles were stable for one month when stored at $-20^{\circ} \mathrm{C}$ and retained their size and transfection efficiency when stored under these conditions and not at 5 and $24^{\circ} \mathrm{C}$, suggesting higher temperatures not suitable for stability of the chitosan nanoparticles [60]. Taken together with the available laboratory evidences, gene delivery through chitosan particles seems to hold a great promise for the future. 
Page 4 of 10

\section{Chitosan in Wound Healing}

Chitosan is known to have potent intrinsic antimicrobial property and in addition to this, chitosan has also been found to exhibit efficiency in delivering antimicrobial agents having beneficial effect on wound healing [62]. Chitosan has been implicated to have effect on homeostasis, inflammation, migration, proliferation and maturation, the five different phases of wound-healing. Chitosan also acts as carrier for growth factors and promotes wound-healing accelerator not only by modulating the functions of inflammatory cells but also by increasing the tensile strength of wounds [62]. Chitosan has been used in treating burn injuries in rats and for skin grafting and bone wound repair in dogs [63]. Chitosan can be made into membranes, nanofibers, scaffolds and has excellent swelling, biodegradable and hydrophilic properties [64]. Various types of delivery formats have been made with chitosan and chitosan derivatives, such as chitosan mesh membrane, to study wound healing [65]. Histological and clinical studies have shown that with the application of chitosan mesh membrane, wound healing was faster with enhanced re-epithelialization and regeneration of granular layer compared to the wound treated without chitosan [65]. Chitosan powder has also been used for treating wounds and it was observed that it took only three weeks to heal the wounds applied with chitosan whereas in control groups without chitosan it took four weeks to heal the wounds [63]. Some workers have used a combination of chitosan, gelatin and curcumin for studying wound closure [66]. Workers have used a matrix composed of cotton fabric with chitosan that is embedded with silver nano particles and other researchers have attempted to combine chitosan and silver nanoparticles for improving wound healing properties chitosan [67]. In addition, chitosan complex with curcumin and tulsi has also been patented in a matrix to promote wound healing. The chitosan films were evaluated for water absorption capacity, tensile strength and anti-bacterial activity in albino rats and the wound healing was better in wounds treated with chitosan composite film along with gentamycin. A hydrogel film made of chitosan and honey was found to be useful in enhancing wound healing due to its flexibility and other properties [68].

Researchers have also constructed nanofibers of chitosan as novel approach of using chitosan for wound healing. Imin-ochitosan was synthesized, its solution was electrospun and the authors obtained nanofiber web ranging from $70-400 \mathrm{~nm}$ and nanofiber webs showed an excellent antimicrobial property [69]. In another communication, electrospun nanofibers of chitosan and poly ethylene oxide were loaded with vascular endothelial growth factor [69] and platelet derived growth factor encapsulated nanoparticles for sustained release of growth factors. These encouraging results show that chitosan nanoparticles inhibited bacterial growth favoring accelerated wound healing and mediated quicker collagen deposition at the wound area [70].

The adhesion of chitosan to the wounded skin surface has also been studied and it was found that double the amount of chitosan formulation remained on the skin surface but the study could not find any difference in the detachment properties in comparison with a synthetic polymer adhesive [68]. More recently, chitosan and nanoparticle based films such as chitosan poly vinyl pyrrolidone nano silver oxide films and titanium dioxide were found more effective in wound healing compared to chitosan alone [71]. These above findings provide ample evidences to suggest that chitosan and chitosan nanoparticles may function as one of the best biopolymers available for wound healing.

\section{Chitosan in Personal Care Applications}

Various formulations of chitosan have been patented for multiple processes and products for functional applications [15]. Being a polymer, chitosan forms a film on hair or the skin, locks the moisture and thus provides sheen appearance to hair and skin. A combination of the salt of pyrithione with chitosan was shown to be a slow release. Chitosonic $^{\oplus}$ acid (Carboxymethyl Caprooyl Chitosan) can also be used in personal care products and Chitosonic ${ }^{\bullet}$ acid has recently been approved by the Personal Care Products Council as new cosmetic ingredient [72]. Interestingly, Chitosonic ${ }^{\bullet}$ acid is water soluble, can form a nano-network structure at concentration higher than $0.5 \%$ and can be made into nanosphere [72]. Chitosonic ${ }^{\circ}$ acid has antimicrobial activities, anti-oxidant function, possesses good hydration activity and has shown less cytotoxicity as tested in L-929 cells [72]. Studies have shown that sulfated chitosan with varying molecular weights exhibited anti-coagulation activity similar to that of heparin [73]. Previous workers have used carboxymethyl chitosan and suggested importance of these chitosan variants in hydrogel and other formats for personal care products such as infant diapers, feminine hygiene and matrices for controlled release [74]. These workers have carried out study showing the structural properties of polyampholytecarboxymethyl chitosan-gpoly hydrogel and they observed the quantity of non-freezing water in the hydrogel appeared to increase gradually as the degree of crosslinking increased [74]. Hence, various studies support the importance and benefit of chitosan and chitosan derived variants for personal care products due to their different unique functional properties like film forming property, water resistance nature, anti-microbial activity, antioxidant activity and nontoxicity.

\section{Chitosan Nanoparticles and Food Packaging}

Over the years there is a tremendous increase in the use of nonbiodegradable materials or plastics derived from petroleum products as food packaging materials. Such uncontrolled use of these materials resulted in the accumulation of plastic waste in the environment and pose serious concerns to the ecosystem [75]. Attempts have also been made from time to time from various parts of the world to address the demand for sustainability and environmental protection by exploring alternative and eco-friendly biomaterials for food packaging industries [76,77]. Hence, biopolymers are the best suitable alternatives to be exploited and developed into eco-friendly food packaging materials due to their biodegradability [78] and among these, chitosan is most favoured naturally available biopolymer. However, the major disadvantages of using chitosan are its poorer mechanical, thermal and barrier properties as compared to the commonly used nonbiodegradable polymers from petroleum. Packing methods employed for such foods is mainly aimed to maintain quality, safety and value of foods [79]. The advancement of nanotechnology has been tremendously helping the progress of the chitosan based materials by the incorporation of newer nanoparticles thereby improving the functional properties of chitosan matrix having tremendous applications in food packaging industry [80]. Due to these properties chitosan films have been used as packing materials for maintaining the quality of preserved foods [81-84].

Many measures and parameters have been considered for "value" added or "active" packaging of foods which include antimicrobial and barrier permeability packing $[85,86]$. Such active packaging system ensures quality assurance, shelf life and safety concerns of the packed foods. Many materials have been used from time to time prepare edible films and coating to pack foods aiming at controlling 
Page 5 of 10

contamination, moisture, oxygen, aroma, freshness etc. Such films and coatings are made from proteins, polysaccharides and lipids which are naturally available $[87,88]$. Chitosan, being a polysaccharide is considered to be a major suitable material for food packaging industry due to many characteristics of chitosan such as nontoxic, biodegradable, anti-microbial, anti-oxidant and ability to form films and blends [81-84,89].Various methods have been employed to prepare chitosan based films for food packaging as summarized previously $[86,90]$ and some of these are 1) chitosan film cross-linked made by Aglycone Geniposidic Acid [91], 2) preparation of glucomannanchitosan-nisin ternary film [92], 3) Ferulic acid incorporated starchchitosan blend film [93], 4) chitosan films by incorporating garlic oil, potassium sorbate and nisin [94] and 5) Antibacterial Ocarboxymethylated chitosan/cellulose blend film from $\mathrm{LiCl} / \mathrm{N}, \mathrm{N}$ dimethylacetamide solution [95]. These above studies and others have suggested that chitosan films are one of the best and biodegradable active packing materials suitable for packaging for foods. Since a large body of evidence is available to demonstrate that addition of chitosan edible films to foods to inhibit microbial load and enhance quality and shelf life of the product $[3,96]$, a brief attempt has been made to summarize the effect of chitosan based films on vegetables, fruits, eggs, fish, cheese and meat produces (Table 1).

\begin{tabular}{|c|c|c|}
\hline Product & Function/Effect & Reference \\
\hline Mango & $\begin{array}{l}\text { Retarded water loss and decline in sensory quality, } \\
\text { inhibited growth of micro organisms }\end{array}$ & [114] \\
\hline $\begin{array}{l}\text { Sponge } \\
\text { Gourd }\end{array}$ & $\begin{array}{l}\text { Reduced weight loss and respiration rate, maintained } \\
\text { firmness and visual appearance. Suppressed } \\
\text { phenylalanine ammonia lyase activity, polyphenol } \\
\text { oxidase and peroxidase activities }\end{array}$ & [115] \\
\hline $\begin{array}{l}\text { Peeled } \\
\text { litchi fruit }\end{array}$ & $\begin{array}{l}\text { Retarded weight loss and decline in sensory quality, } \\
\text { reduced the increase in polyphenol oxidase and } \\
\text { peroxidase activities }\end{array}$ & [116] \\
\hline $\begin{array}{l}\text { Fuji } \\
\text { apples }\end{array}$ & $\begin{array}{l}\text { Retarded enzymatic browning of cut apples, decreased } \\
\text { respiration, transpiration and suppressed softening of } \\
\text { tissues }\end{array}$ & [117] \\
\hline Papaya & $\begin{array}{l}\text { Micronized chitosan retarded water loss, inhibited the } \\
\text { growth of microorganisms, retained the color and } \\
\text { increased shelf life }\end{array}$ & [118] \\
\hline $\begin{array}{l}\text { Orange } \\
\text { juice }\end{array}$ & $\begin{array}{l}\text { Chitosan at lower optimall concentration of } 1 \mathrm{~g} \mathrm{~L}-1 \\
\text { extended the quality, reduced enzymatic and non- } \\
\text { enzymatic browning, reduced spoilage, maintained } \\
\text { ascorbic acid and carotenoid levels }\end{array}$ & [119] \\
\hline Mango & $\begin{array}{l}\text { Chitosan alone decreased decay of fruit during storage, } \\
\text { weight loss, delayed coloring, } \mathrm{pH} \text { and titratable acidity. } \\
\text { Chitosan with teapolyphenol enhanced shelf life } \\
\text { extension }\end{array}$ & [120] \\
\hline $\begin{array}{l}\text { Strawberr } \\
\text { ies }\end{array}$ & $\begin{array}{l}\text { Delayed weight loss, decay percentage, titratable } \\
\text { acidity, pH, total soluble solids. Maintained higher } \\
\text { concentrations of total phenolics and total anthocyanins }\end{array}$ & [121] \\
\hline $\begin{array}{l}\text { Fresh cut } \\
\text { Mushroo } \\
\mathrm{m}\end{array}$ & $\begin{array}{l}\text { Delayed discoloration associated with reduced enzyme } \\
\text { activities of laccase, phenylalanine ammonia lyase, } \\
\text { peroxidase, catalase and polyphenoloxidase. In } \\
\text { addition reduced enzyme activities of cellulase, total } \\
\text { amylase and a-amylase thereby slowed down texture }\end{array}$ & [122] \\
\hline $\begin{array}{l}\text { Carrot } \\
\text { shreds }\end{array}$ & $\begin{array}{l}\text { Chitosan alone could retain better color, superior } \\
\text { sensory, lower microbial load and retain vitamin } \mathrm{C} \text {. } \\
\text { Chitosan with citric acid treatment retained beta } \\
\text { carotene }\end{array}$ & [123] \\
\hline
\end{tabular}

\begin{tabular}{|l|l|l|}
\hline $\begin{array}{l}\text { Table } \\
\text { grapes }\end{array}$ & $\begin{array}{l}\text { Chitosan lowered weight loss, berry decay, browning, } \\
\text { shattering, and cracking. Retained total soluble solids, } \\
\text { titratable acidity and their ratio. Delayed changes of the } \\
\text { total phenolics, catechin, and antioxidant }\end{array}$ & {$[124]$} \\
\hline $\begin{array}{l}\text { Mozzarell } \\
\text { a Cheese }\end{array}$ & $\begin{array}{l}\text { Lactic acid chitosan solution added to the starter } \\
\text { inhibited growth of coliform and Pseudomona spoilage } \\
\text { microorganisms, no effect on lactic acid bacteria and } \\
\text { increased shelf life }\end{array}$ & {$[125]$} \\
\hline $\begin{array}{l}\text { Egg shelf } \\
\text { life }\end{array}$ & $\begin{array}{l}\text { Weight loss decreased and increased shelf life by 2 to } \\
3 \text { weeks at 25C after chitosan coating }\end{array}$ & {$[126]$} \\
\hline $\begin{array}{l}\text { Sausage } \\
\text { s }\end{array}$ & $\begin{array}{l}\text { Maintained color, sensorial properties and inhibited } \\
\text { microbial counts for extended shelf life }\end{array}$ & {$[127]$} \\
\hline $\begin{array}{l}\text { Salamon } \\
\text { fillets }\end{array}$ & $\begin{array}{l}\text { Reduced total volatile base nitrogen, trimethylamine, } \\
\text { thiobarbituric acid, ATP breakdown products and pH, } \\
\text { lowered the microbial growth }\end{array}$ & {$[128]$} \\
\hline $\begin{array}{l}\text { Tilapia } \\
\text { fillets }\end{array}$ & $\begin{array}{l}\text { Extended shelf life two fold and reduced spoilage due } \\
\text { to relevant bacteraia isolates in Tilapia }\end{array}$ & {$[13]$} \\
\hline Fish & $\begin{array}{l}\text { Chitosan with Thymus vulgaris essential oil lower pH, } \\
\text { thiobarbituric acid, and total volatile basic nitrogen } \\
\text { values and increased shelf life by six days }\end{array}$ & {$[129]$} \\
\hline $\begin{array}{l}\text { Silver } \\
\text { carp } \\
\text { fillets }\end{array}$ & $\begin{array}{l}\text { Nanochitosan inhibited the total volatile base nitrogen } \\
\text { content and exhibited higher antimicrobial activity than } \\
\text { chitosan }\end{array}$ & {$[130]$} \\
\hline
\end{tabular}

Table 1: Edible Chitosan coating/films improves shelf life of natural products.

\section{Chitosan based nanocomposites}

Modifications or alterations were attempted to improve the functional characteristics of chitosan such as the use of chitosan composites [80]. Efforts were made to prepare chitin whiskers by acid hydrolysis of chitin by various scientific teams and obtained various dimensions of whiskers ranging length from $417 \mathrm{~nm}-500 \mathrm{~nm}$ and width $33 \mathrm{~nm}-50 \mathrm{~nm}[97,98]$. It is understood that nanoreinforcement is more suitable for biopolymers like chitosan for increasing their functional properties as compared to commonly used petroleum derived polymers. Such nano-reinforcement, in fact, may have more benefit in managing cost besides improving the properties of chitosan type biopolymers [99]. The chitin whiskers were found to improve tensile strength and water resistance of the matrix when added to soyprotein isolates thermoplastics [97]. Similarly, when chitosan whiskers were added to chitosan films, it was observed that whiskers enhanced the tensile strength and water resistance of the chitosan films [98]. Chitosan nanoparticles can be prepared by ionic gelation [100] and it was found that incorporation of chitosan-tripolyphosphate nanoparticles in hydroxyproponyl methylcellulose increased the mechanical and barrier functions of the films [101].

Methods of using reinforcing fillers (nanofillers) with specific dimensions helped to obtain specific chitosan composites with improved mechanical and barrier functions of matrix chitosan [102-105]. The poor properties of chitosan can be improved by the incorporation of nano-reinforcement into the chitosan polymer. Nanocomposites of chitosan have many applications in various areas of human health care management such as medicine, food industry, paper industry, etc. Chitosan is known to form nanocomposites with montmorillonite (MMT) and represent an excellent sorbent material [106]. These chitosan-based composites films and coating provide 
Citation: Radhakrishnan Y, Gopal G, Lakshmanan CC, Nandakumar KS (2015) Chitosan Nanoparticles for Generating Novel Systems for Better Applications: A Review. J Mol Genet Med S4: 005. doi:10.4172/1747-0862.S4-005

Page 6 of 10

promising advantage for food packaging industry due to their ability to support the shelf life of food products [107-109].

The functional properties of chitosan nanocomposites mainly depend on the nanofillers and the physical properties of nanofillers such as shape, size etc. A nanofiller particle has to be at the nanometer scale of r100 and various types of nanofillers have been reported and described [80]. Hence, the types, size, surface areas and other physical and chemical properties of nanofillers can greatly enhance the functional properties of the chitosan based nanocomposites and these depend on the ratio of particle length to thickness among particles, platelets and fibers (Figure 1). It was observed that clay loading nanocomposite films were found to have improved oxygen barrier than neat chitosan film. Hence the incorporation of clay to the chitosan matrix is known to improve the permeability and barrier properties and these clay-chitosan nanocomposite films seem suitable for food packaging and protective coatings [80]. Table 2 depicts various types of nanofillers used for chitosan polymer, various types of composites, preparation and their applications [80].

\begin{tabular}{|c|c|c|c|c|}
\hline $\begin{array}{l}\text { Nanofiller } \\
\text { type }\end{array}$ & $\begin{array}{l}\text { Nano } \\
\text { material } \\
\text { used }\end{array}$ & Nanocmposite & $\begin{array}{l}\text { Preparation } \\
\text { method for } \\
\text { chitosan } \\
\text { nanocompo } \\
\text { site }\end{array}$ & Application \\
\hline \multirow[t]{6}{*}{ Particles } & \multicolumn{4}{|l|}{ Metal oxide } \\
\hline & $\begin{array}{ll}\mathrm{ZrO}_{2} & \mathrm{Fe}_{3} \mathrm{O}_{4} \\
\mathrm{SiO}_{2} & \mathrm{Cu}_{2} \mathrm{O} \\
\mathrm{TiO}, & \mathrm{ZnO}, \\
\mathrm{Al}_{2} \mathrm{O}_{3} & \end{array}$ & $\begin{array}{l}\text { Thin films, } \\
\text { hydrogel, } \\
\text { powder }\end{array}$ & $\begin{array}{l}\text { Electrophoret } \\
\text { ic deposition, } \\
\text { ultrasonicatio } \\
\mathrm{n} \text {, } \\
\text { electrochemi } \\
\text { cal } \\
\text { deposition, } \\
\text { solution } \\
\text { mixing, and } \\
\text { freeze drying }\end{array}$ & $\begin{array}{l}\text { Biosensor } \\
\text { for nucleic } \\
\text { acid, drug } \\
\text { delivery, } \\
\text { enzyme } \\
\text { immobilizati } \\
\text { on, photo- } \\
\text { catalysis, } \\
\text { water } \\
\text { purification, } \\
\text { tissue } \\
\text { engineering, } \\
\text { UV protection of } \\
\text { fabric, and } \\
\text { water } \\
\text { treatment }\end{array}$ \\
\hline & \multicolumn{4}{|l|}{ Metals } \\
\hline & $\begin{array}{l}\mathrm{Ag} \\
\mathrm{Au} \\
\mathrm{Pt} \\
\mathrm{Pd} \\
\mathrm{Co} \\
\mathrm{Ni}\end{array}$ & $\begin{array}{l}\text { Thin film, } \\
\text { hydrogels }\end{array}$ & $\begin{array}{l}\text { Solution } \\
\text { mixing, spin } \\
\text { coating, dip } \\
\text { coating, co- } \\
\text { precipitation, } \\
\text { and electro- } \\
\text { chemical } \\
\text { deposition }\end{array}$ & $\begin{array}{l}\text { Cell } \\
\text { stimulation, } \\
\text { antibacterial } \\
\text { coatings, } \\
\text { biosensor, } \\
\text { catalysts, } \\
\text { etc. }\end{array}$ \\
\hline & \multicolumn{4}{|l|}{ Other } \\
\hline & $\begin{array}{l}\text { Bioactive } \\
\text { glass, CdS } \\
\text { Quantum } \\
\text { dots }\end{array}$ & $\begin{array}{l}\text { Hydrogel, } \\
\text { powder, }\end{array}$ & $\begin{array}{l}\text { Solution } \\
\text { mixing and } \\
\text { freeze drying }\end{array}$ & $\begin{array}{l}\text { Thermo- } \\
\text { responsive } \\
\text { injectable } \\
\text { scaffolds, } \\
\text { tissue } \\
\text { engineering, } \\
\text { and latent } \\
\text { finger mark } \\
\text { detection }\end{array}$ \\
\hline Fibers & $\begin{array}{l}\text { SWCNTsMW } \\
\text { CNTsFe } \\
\text { nanowire, }\end{array}$ & $\begin{array}{l}\text { Composite } \\
\text { fibers, powder, } \\
\text { films }\end{array}$ & $\begin{array}{l}\text { Solution } \\
\text { spinning, } \\
\text { freeze drying, }\end{array}$ & $\begin{array}{l}\mathrm{pH}, \\
\text { electrical } \\
\text { actuators, }\end{array}$ \\
\hline
\end{tabular}

\begin{tabular}{|c|c|c|c|c|}
\hline & $\begin{array}{l}\mathrm{ZnO} \\
\text { nanowires } \\
\text { Au nanowire, } \\
\text { nanorod } \\
\text { Cellulose } \\
\text { fibers }\end{array}$ & & $\begin{array}{l}\text { solution } \\
\text { mixing, and } \\
\text { sonication }\end{array}$ & $\begin{array}{l}\text { bone tissue } \\
\text { engineering, } \\
\text { biological } \\
\text { probe, } \\
\text { electro- } \\
\text { chemical } \\
\text { biosensors, } \\
\text { and paper } \\
\text { coating }\end{array}$ \\
\hline \multirow[t]{2}{*}{ Platelets } & $\begin{array}{l}\text { Layered } \\
\text { silicates }\end{array}$ & $\begin{array}{l}\text { Film, scaffolds, } \\
\text { powder }\end{array}$ & $\begin{array}{l}\text { Solution } \\
\text { mixing, } \\
\text { freeze drying, } \\
\text { and micro- } \\
\text { emulsion } \\
\text { process }\end{array}$ & $\begin{array}{l}\text { Fuel cell, } \\
\text { gas } \\
\text { separation, } \\
\text { drug } \\
\text { delivery, } \\
\text { water } \\
\text { treatment, } \\
\text { and } \\
\text { catalysis }\end{array}$ \\
\hline & $\begin{array}{l}\text { Graphene, } \\
\text { Graphene } \\
\text { oxide }\end{array}$ & Films, powder & $\begin{array}{l}\text { Solution } \\
\text { casting and } \\
\text { mixing }\end{array}$ & $\begin{array}{l}\text { Biosensing } \\
\text { and electro- } \\
\text { chemical } \\
\text { sensing }\end{array}$ \\
\hline
\end{tabular}

Table 2: Summary of various nanofillers used in chitosan matrix, the nanocomposite types, and their preparation methods and targeted applications ${ }^{*}$.

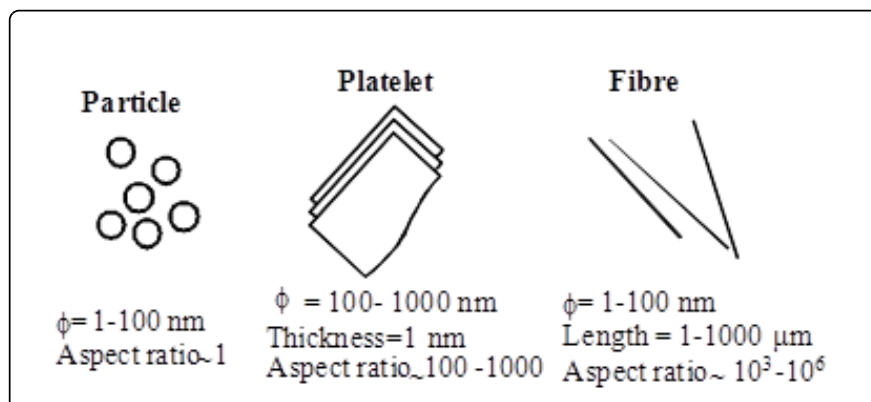

Figure 1: Various nanofiller shapes and typical aspect ratios. Reproduced with permission from Pillai and Ray [80].

As an alternative to plastic materials, Mura et al. reported the excellent improvement in the mechanical properties of a nanostructured film composed of chitosan, methylcellulose and silica nanoparticles which may replace plastic for packaging foods thereby reducing the environmental pollution by plastics [110]. Another interesting work done by de Moura et al. show the application of chitosan nanoparticles-carboxymethylcellulose films [111]. Chitosan nanoparticles ranging from $8-110 \mathrm{~nm}$ were used to make chitosan nanoparticles-carboxhymethyl cellulose films with better mechanical and thermal properties. This study supports, as authors argue, that carboxymethyl cellulose films with chitosan nanoparticles prepared would provide a suitable material for food and beverage packaging applications [111].

Attempt was also made to increase the hydrophobicity of chitosan by making Dodecenyl succinylated phthaloyl chitosan (DS-g-PHCTS) films without affecting anti-bacterial activity of chitosan and thus increasing functional properties of chitosan which appears more suitable in food packaging and coating [112]. Similar to this, Bordenave et al. carried out studies to increase water resistance of 
chitosan and paper based materials for environmentally friendly food packaging materials [113]. In this study these workers have made special chitosan-papers by coating papers with chitosan-palmitic acid emulsions or with a blend of chitosan and O,O'-dipalmitoylchitosan (DPCT) and thus improved the liquid water resistance and antibacterial activity suggesting the importance of these chitosan and paper based materials having much biodegradability. To conclude, considering the recent research progress, industrial demand and environmental sustainable issues, the use and application of chitosan and chitosan derived materials for active packaging for food industry are very promising.

\section{Future Research}

Present environmental scenario and sustainability issues force the industries to search for natural alternatives instead of synthetic polymers for various applications. Chitosan and chitosan nanoderivatives are one of the best known and studied natural polymers with versatile functions. However, the major concern with the use of macro, micro or nano chitosan material, especially in food industry is the cost and less functional performance compared to the conventionally available synthetic polymers.

The future research relating to chitosan and nanochitosan containing materials should be based on the current caveats and pitfalls in using chitosan. There are a few concerns that need to be addressed on top priority to have a wide acceptance of applications of chitosan materials viz. i) quality of the chitosan particles needs to be established ii) oligosaccharide engineering for chitosan applications as food additives needs to be studied in detail, iii) stability of chitosan composites especially used for transfer of biomolecules such as transfection process needs to be improved, since current operating temperature are in a narrow range, iv) improvement in the mechanical, thermal and barrier properties compared to synthetic polymers and v) reduction of inconsistency of raw material specification such as the molecular weight and the acetylation content.

Albeit chitosan compositions are known to be nontoxic and nonallergenic, supporting evidences may be made available to support the fact that chitosan and chitosan derivatives have least effect on humans under long term exposure and consumption. The limited exposure is due to the differential regulatory approval regimes across the globe. Only few regulatory agencies or countries have proposed the use of chitosan compositions for multiple applications such as US FDA (GRAS status), approval for use in water purification upto $10 \mathrm{mg} / \mathrm{L}$ of potable water by US EPA and as food additive in Japan and Korea. Uniform globally acceptable criteria shall be established to determine the quality and characters of modified chitosan biopolymer for human use

Future research in the areas of food, food packaging and personal care needs to focus on the "value added packaging" or active packaging. Vargas and Gonzalez-Martinez proposed that chitosan inclusion into recycling composite materials for food packaging [15]. In addition, attempts may be made to make multilayer packaging where in the synthetic polymer may act as liquid barrier, while the nanochitosan layer would impart antioxidant benefit as oxygen barrier. Furthermore, blends of chitosan with other chemicals or molecules such as chitosan silver, chitosan pectin and chitosan natural biomolecules towards antimicrobial efficacy may be studied in detail with an approach to make such composites at industry level. Development of chitosan biosensors for purification of water or for clarifying juices will be a useful tool for screening and packaging. It is also necessary to establish the compatibility and feasibilities of these chitosan nanomaterials with different types of food items. It also remains to study how the nature and characteristics of food items stored would affect the stability and functional characteristics of chitosan nanomaterials used for packaging these foods.

It is a paramount importance that the chemical methods used for preparations of chitosan and its nanoparticle varieties shall be well established, validated and which are scalable at industrial level. Therefore, the simple and low cost production process of chitosan derived nanoparticles having valuable application in human health care management need to be established. Even chemical, physical and other qualities and characteristics of such chitosan derived materials should be well tested and analytically established. Industry supported private and academic research amalgamated with regulatory agencies would accelerate the development of such naturally available chitosan and chitosan derivatives for human use. These combined efforts to develop chitosan derived products would certainly support environmental sustainability for human health and existence of other living system.

\section{Acknowledgement}

The views expressed in the article are solely from individual authors and do not represent the view of the organization.

\section{References}

1. Benjakul S, Visessanguan W, Tanaka M (2003) Partial purification and characterization of trimethylamine-N-oxide demethylase from lizardfish kidney. Comp Biochem Physiol B Biochem Mol Biol 135: 359-371.

2. Dutta PK, Dutta J, Tripathi VS (2004) Chitin and chitosan: Chemistry, properties and applications. Journal of Scientific and Industrial Research 63: 20-23.

3. No HK, Meyers SP, Prinyawiwatkul W, Xu Z (2007) Applications of chitosan for improvement of quality and shelf life of foods: a review. J Food Sci 72: R87-100.

4. Singh K, Mishra A (2015) Chitosan nanopariculate and their applications: A review. Int J Pharm Bio Sci 6: 557 - 566.

5. Berthold A, Cremer K, Kreuter J (1996) Preparation and characterization of chitosan microspheres as drug carrier for prednisolone sodium phosphate as model for Anti-Inflammatory Drugs. Journal of Controlled Release 9: 17-25.

6. Mehrotra A, Nagarwal RC, Pandit JK (2011) Lomustine loaded chitosan nanoparticles: characterization and in-vitro cytotoxicity on human lung cancer cell line L132. Chem Pharm Bull (Tokyo) 59: 315-320.

7. Ohya Y, Takei T, Kobayashi H, Ouchi T (1993) Release behaviour of 5fluorouracil from chitosan-gel microspheres immobilizing 5-fluorouracil derivative coated with polysaccharides and their cell specific recognition. J Microencapsul 10: 1-9.

8. Patil P, Bhoskar M (2014) Optimization and evaluation of spray dried chitosan nanopaparticles containing doxorubicin. Int J Curr Pharma Res 6: 7-15.

9. Allémann E, Leroux JC, Gurny R, Doelker E (1993) In vitro extendedrelease properties of drug-loaded poly(DL-lactic acid) nanoparticles produced by a salting-out procedure. Pharm Res 10: 1732-1737.

10. Du WL, Niu SS, Xu YL, Xu ZR, Fan CL (2009) Antibacterial activity of chitosan tripolyphosphate nanoparticles loaded with various metal ions. Carbohydrate Polymers 75: 385-389.

11. Kim K, Kim JH, Park H, Kim YS, Park K, et al. (2010) Tumor-homing multifunctional nanoparticles for cancer theragnosis: Simultaneous diagnosis, drug delivery, and therapeutic monitoring. J Control Release 146: 219-227. 
12. Agulló E, Rodríguez MS, Ramos V, Albertengo L (2003) Present and Future Role of Chitin and Chitosan in Food. Macromolecular Bioscience 3: 521-530.

13. Cao R, Liu Q, Yin B, Wu B (2012) Chitosan extends the shelf-life of filleted tilapia (Oreochromis niloticus ) during refrigerated storage. Journal of Ocean University of China 11: 408-412.

14. Kamil J, Jeon Y, Shahidi F (2002) Antioxidative activity of chitosans of different viscosity in cooked comminuted flesh of herring (Clupea harengus). Food Chemistry 79: 69-77.

15. Vargas M, González-Martínez C (2010) Recent patents on food applications of chitosan. Recent Pat Food Nutr Agric 2: 121-128.

16. Jean M, Alameh M, De Jesus D, Thibault M, Lavertu M, et al. (2012) Chitosan-based therapeutic nanoparticles for combination gene therapy and gene silencing of in vitro cell lines relevant to type 2 diabetes. Eur J Pharm Sci 45: 138-149.

17. de Paula Pansani Oliveira F, Dalla Picola IP, Shi Q, Barbosa HF, Tiera VA, et al. (2013) Synthesis and evaluation of diethylethylamine-chitosan for gene delivery: composition effects on the in vitro transfection efficiency. Nanotechnology 24: 055101.

18. Kuang Y, Yuan T, Zhang Z, Li M, Yang Y (2012) Application of ferriferous oxide modified by chitosan in gene delivery. J Drug Deliv 2012: 920764.

19. Goy RC, Britto D, Assis OBG (2009) A review of the antimicrobial activity of chitosan. Polímeros: Ciencia e Techologia 19: 1-7.

20. Ing LY, Zin NM, Sarwar A, Katas H (2012) Antifungal activity of chitosan nanoparticles and correlation with their physical properties. Int J Biomater 2012: 632698.

21. Qi L, Xu Z, Jiang X, Hu C, Zou X (2004) Preparation and antibacterial activity of chitosan nanoparticles. Carbohydr Res 339: 2693-2700.

22. Rabea EI, Badawy ME, Stevens CV, Smagghe G, Steurbaut W (2003) Chitosan as antimicrobial agent: applications and mode of action. Biomacromolecules 4: 1457-1465.

23. Jeon SJ, Oh M, Yeo WS, Galvão KN, Jeong KC (2014) Underlying mechanism of antimicrobial activity of chitosan microparticles and implications for the treatment of infectious diseases. PLoS One 9: e92723.

24. Rhoades J, Roller S (2000) Antimicrobial actions of degraded and native chitosan against spoilage organisms in laboratory media and foods. Appl Environ Microbiol 66: 80-86.

25. Kiskó G, Sharp R, Roller S (2005) Chitosan inactivates spoilage yeasts but enhances survival of Escherichia coli O157:H7 in apple juice. J App Microbiol 98: 872-880.

26. Abd AJ, Niamah AK (2012) Effect of chitosan on apple juice quality. International Journal of Agricultural and Food Science 2: 153-157.

27. Lahmer RA, Williams AP, Townsend S, Baker S, Jones DL (2012) Antibacterial action of chitosan-arginine against Escherichia coli O157 in chicken juice. Food Control 26: 206-211.

28. Garai P, Gogoi M, Gopal G, Radhakrishnan Y, Nandakumar KS, et al. (2014) The basics and advances of immunomodulators and antigen presentation: a key to development of potent memory response against pathogens. Expert Opin Biol Ther 14: 1383-1397.

29. Gnanadhas DP, Ben Thomas M, Elango M, Raichur AM, Chakravortty D (2013) Chitosan-dextran sulphate nanocapsule drug delivery system as an effective therapeutic against intraphagosomal pathogen Salmonella. J Antimicrob Chemother 68: 2576-2586.

30. Barreteau H, Delattre C, Michaud P (2006) Production of Oligosaccharides as promising new food additive generation. Food Technol Biotechnol 44 323-333.

31. Kardas I, Struszczyk MH, Kucharska M, Van den Broek LAM, van Dam JEG, Ciechanska D (2012) Chitin and Chitosan as Functional Biopolymers for Industrial Applications. In: Navard P (ed) The European Polysaccharide Network of Excellence (EPNOE) Research Initiatives and Results Springer-Verlag Wien, pp. 329-375

32. Ravi Kumar MNV (2000) A review of chitin and chitosan applications. React Funct Poly 46: 1-27.
33. Suman SP, Mancini RA, Joseph P, Ramanathan R, Konda MK, et al (2010) Packaging-specific influence of chitosan on color stability and lipid oxidation in refrigerated ground beef. Meat Sci 86: 994-998.

34. Mokhtar SM, Youssef KM, Morsy NE (2014)The effects of natural antioxidants on colour, lipid stability and sensory evaluation of fresh beef patties stored at $4^{\circ} \mathrm{C}$. Journal of Agroalimentary Processes and Technologies 20: 282-292.

35. Wan A, Xu Q, Sun Y, Li H (2013) Antioxidant activity of high molecular weight chitosan and N,O-quaternized chitosans. J Agric Food Chem 61: 6921-6928.

36. Yen MT, Yang JH, Mau JL (2008) Antioxidant properties of chitosan from crab shells Carbohydrate Polymers 74: 840-844.

37. Rajalakshmi A, Krithiga N, Jayachitra A (2013) Antioxidant activity of the chitosan extracted from shrimp exoskeleton. Middle-east $J$ of Scientific Res 16: 1446-1451.

38. Jarmila V, Vavríková E (2011) Chitosan derivatives with antimicrobial, antitumour and antioxidant activities--a review. Curr Pharm Des 17: 3596-3607.

39. López-Mata MA, Ruiz-Cruz S, Silva-Beltrán NP, Ornelas-Paz Jde J, Zamudio-Flores PB, et al. (2013) Physicochemical, antimicrobial and antioxidant properties of chitosan films incorporated with carvacrol. Molecules 18: 13735-13753.

40. Sun T, Zhou D, Xie J, Mao F (2007) Preparation of chitosan oligomers and their antioxidant activity. Eur Food Res Technol 225: 451-456.

41. Muzzarelli RA (1999) Clinical and biochemical evaluation of chitosan for hypercholesterolemia and overweight control. EXS 87: 293-304.

42. Mhurchu CN, Poppitt SD, McGill AT, Leahy FE, Bennett DA, et al. (2004) The effect of the dietary supplement, Chitosan, on body weight: a randomised controlled trial in 250 overweight and obese adults. Int J Obes Relat Metab Disord 28: 1149-1156.

43. Espinal-Ruiz M, Parada-Alfonso F, Restrepo-Sánchez LP, NarváezCuenca CE, McClements DJ (2014) Impact of dietary fibers [methyl cellulose, chitosan, and pectin] on digestion of lipids under simulated gastrointestinal conditions. Food Funct 5: 3083-3095.

44. Kerch G (2015) The potential of chitosan and its derivatives in prevention and treatment of age-related diseases. Mar Drugs 13: 2158-2182.

45. Liu SH, Chang YH, Chiang MT (2010) Chitosan reduces gluconeogenesis and increases glucose uptake in skeletal muscle in streptozotocin-induced diabetic rats. J Agric Food Chem 58: 5795-5800.

46. Bokura H, Kobayashi S (2003) Chitosan decreases total cholesterol in women: a randomized, double-blind, placebo-controlled trial. Eur J Clin Nutr 57: 721-725.

47. Patti AM, Katsiki N, Nikolic D, Al-Rasadi K, Rizzo M (2015) Nutraceuticals in lipid-lowering treatment: a narrative review on the role of chitosan. Angiology 66: 416-421.

48. Yao HT, Chiang MT (2006) Chitosan shifts the fermentation site toward the distal colon and increases the fecal short-chain fatty acids concentrations in rats. Int J Vitam Nutr Res 76: 57-64.

49. Han XY, Du WL, Fan CL, Xu ZR (2010) Changes in composition a metabolism of caecal microbiota in rats fed diets supplemented with copper-loaded chitosan nanoparticles. J Anim Physiol Anim Nutr (Berl) 94: e138-144.

50. Saranya N, Moorthi A, Saravanan S, Devi MP, Selvamurugan N (2011) Chitosan and its derivatives for gene delivery. Int J Biol Macromol 48: 234-238.

51. Chen H, Cui S, Zhao Y, Wang B, Shang S, Chen H, Peng X (2012) OAlkylation of chitosan for gene delivery by using ionic liquid in an in-situ reactor. Engineering 5: 114-117.

52. Deng J, Zhou Y, Xu B, Mai K, Deng Y, et al. (2011) Dendronized chitosan derivative as a biocompatible gene delivery carrier. Biomacromolecules 12: 642-649.

53. Lu H, Dai Y, Lv L, Zhao H (2014) Chitosan-graft-polyethylenimine/DNA nanoparticles as novel non-viral gene delivery vectors targeting osteoarthritis. PLoS One 9: e84703. 
54. Köping-Höggård M, Tubulekas I, Guan H, Edwards K, Nilsson M, et al. (2001) Chitosan as a nonviral gene delivery system. Structure-property relationships and characteristics compared with polyethylenimine in vitro and after lung administration in vivo. Gene Ther 8: 1108-1121.

55. Thanou M, Florea BI, Geldof M, Junginger HE, Borchard G (2002) Quaternized chitosan oligomers as novel gene delivery vectors in epithelial cell lines. Biomaterials 23: 153-159.

56. Li HY, Birchall J (2006) Chitosan-modified dry powder formulations for pulmonary gene delivery. Pharm Res 23: 941-950.

57. Dastan $\mathrm{T}$, Turan K (2004) In vitro characterization and delivery of chitosan-DNA microparticles into mammalian cells. J Pharm Pharm Sci 7: 205-214.

58. Lavertu M, Méthot S, Tran-Khanh N, Buschmann MD (2006) High efficiency gene transfer using chitosan/DNA nanoparticles with specific combinations of molecular weight and degree of deacetylation. Biomaterials 27: 4815-4824.

59. Cavalli R, Bisazza A, Trotta M, Argenziano M, Civra A, et al. (2012) New chitosan nanobubbles for ultrasound-mediated gene delivery: preparation and in vitro characterization. Int J Nanomedicine 7: 3309-3318.

60. Mohammadi Z, Dorkoosh FA, Hosseinkhani S, Amini T, Rahimi AA, et al. (2012) Stability studies of chitosan-DNA-FAP-B nanoparticles for gene delivery to lung epithelial cells. Acta Pharm 62: 83-92.

61. Mohammadi Z, Abolhassani M, Dorkoosh FA, Hosseinkhani S, Gilani K, et al. (2011) Preparation and evaluation of chitosan-DNA-FAP-B nanoparticles as a novel non-viral vector for gene delivery to the lung epithelial cells. Int J Pharm 409: 307-313.

62. Dai T, Tanaka M, Huang YY, Hamblin MR (2011) Chitosan preparations for wounds and burns: antimicrobial and wound-healing effects. Expert Rev Anti Infect Ther 9: 857-879.

63. El-Husseiny IN, Ahmed KA (2012) Application of chitosan for wound repair in dogs. Life Sci Journal 9: 196 -203.

64. Archana D, Dutta J, Dutta PK (2013) Evaluation of chitosan nano dressing for wound healing: characterization, in vitro and in vivo studies. Int J Biol Macromol 57: 193-203.

65. Azad AK, Sermsintham N, Chandrkrachang S, Stevens WF (2004) Chitosan membrane as a wound-healing dressing: characterization and clinical application. J Biomed Mater Res B Appl Biomater 69: 216-222.

66. Nguyen VC, Nguyen VB, Hsieh MF (2013) Curcumin-loaded chitosan/ gelatin composite sponge for wound healing application. Int J Polymer Sci 2013.

67. Ahamed MLN, Sastry TP (2011) Wound dressing application of chitosan based bioactive compounds. Int J Pharm Life Sci 2: 991 -996.

68. Hurler J, Skalko-Basnet N (2012) Potentials of chitosan-based delivery systems in wound therapy: bioadhesion study. J Funct Biomater 3: 37-48.

69. Nawalkhe RG, Hudson SM, Seyam AFM, Waly AI, Abou-Seid NY, Ibrahim HM (2012) Development of electrospun iminochitosan for improved wound healing application. J Engineered Fibers and Fabrics 7: 47-55.

70. Xie Z, Paras CB, Weng H, Punnakitikashem P, Su LC, et al. (2013) Dual growth factor releasing multi-functional nanofibers for wound healing. Acta Biomater 9: 9351-9359.

71. Archana D, Singh BK, Dutta J, Dutta PK (2015) Chitosan-PVP-nano silver oxide wound dressing: in vitro and in vivo evaluation. Int J Biol Macromol 73: 49-57.

72. Lee SM, Liu KH, Liu YY, Ghang YP, Lin CC, Chen YS (2013) Chitosonic acid as a novel cosmetic ingredient : Evaluation of its antimicrobial, antioxidant and hydration activities. Materials 6: 1391-1402.

73. Vongchan P, Sajomsang W, Subyen D, Kongtawelert P (2002) Anticoagulant activity of a sulfated chitosan. Carbohydr Res 337: 1239-1242.

74. Yu C, Liu YF, Tang HL, Tan HM (2010) Study of carboxymethyl chitosan - based polyampholyte superabsorbent polymer (part II): Investigating the state of water in CMCTS-g-(PAA-co-PTMAAC) hydrogel. Iranian Polymer Journal 19: 417 - 425 .
75. Avella M, De Vlieger JJ, Errico ME, Fischer S, Vacca P, Volpe MG (2005) Biodegradable starch/clay nanocomposite films for food packaging applications. Food Chemistry 93: 467-474.

76. Jayaramudu J, Reddy GS, Varaprasad K, Sadiku ER, Sinha Ray S, et al. (2013) Preparation and properties of biodegradable films from Sterculia urens short fiber/cellulose green composites. Carbohydr Polym 93: $622-627$

77. Majeed K, Jawaid M, Hassan A, Bakar A, Khalil H, Salema A (2013) Potential materials for food packaging from Nanoclay/Natural fibres filled hybrid composites. Materials and Design 46: 391-410.

78. Tang XZ, Kumar P, Alavi S, Sandeep KP (2012) Recent advances in biopolymers and biopolymer-based nanocomposites for food packaging materials. Crit Rev Food Sci Nutr 52: 426-442.

79. Debeaufort F, Quezada-Gallo JA, Voilley A (1998) Edible films and coatings: tomorrow's packagings: a review. Crit Rev Food Sci Nutr 38: 299-313.

80. Pillai SK, Ray SS (2012) Chitosan-based Nanocomposites. In: Maya, J. Sabu,T. (eds) Natural Polymers. In: Maya J, Sabu T (eds) Vol 2 Nanocomposites The Royal Society of Chemistry, RSC Green Chemistry, pp. 33-45 http://dx.doi.org/ 10.1039/9781849735 315-00033.

81. Park SI, Zhao Y (2004) Incorporation of a high concentration of mineral or vitamin into chitosan-based films. J Agric Food Chem 52: 1933-1939.

82. Suyatma NE, Tighzert L, Copinet A, Coma V (2005) Effects of hydrophilic plasticizers on mechanical, thermal, and surface properties of chitosan films. J Agric Food Chem 53: 3950-3957.

83. Tsai GJ, Su WH (1999) Antibacterial activity of shrimp chitosan against Escherichia coli. J Food Prot 62: 239-243.

84. Wu T, Zivanovic S, Draughon FA, Conway WS, Sams CE (2005) Physicochemical properties and bioactivity of fungal chitin and chitosan. J Agric Food Chem 53: 3888-3894.

85. Brody AL (2001) What's the hottest food packaging technology today? Food Technol 5: 82-84.

86. Tripathi S, Mehrotra GK, Dutta PK (2008) Chitosan based antimicrobial films for food packaging applications. e-Polymers 093: 1-7.

87. Greener-Donhowe I, Fennema O (1994) Edible films and coatings:Characteristics, formation, definitions, and testing methods. In: Krochta JM, Baldwin EA, Nisperos-Carriedo M (eds) Edible coatings and films to improve food quality, Technomic Publishing, Lancaster, PA, pp. $1-2$.

88. Krochta J, de Mulder-Johnston CD (1997) Edible and biodegradable polymer films: challenges and opportunities. Food Technology 51: 61-74.

89. Wang G (1992) Inhibition and inactivation of five species of foodborne pathogens by chitosan. Journal of Food Protection 55: 916-919.

90. Tripathi S, Mehrotra GK, Dutta PK (2009) Physicochemical and bioactivity of cross-linked chitosan-PVA film for food packaging applications. Int J Biol Macromol 45: 372-376.

91. Mi FL, Huang CT, Liang HF, Chen MC, Chiu YL, et al. (2006) Physicochemical, antimicrobial, and cytotoxic characteristics of a chitosan film cross-linked by a naturally occurring cross-linking agent, aglycone geniposidic acid. J Agric Food Chem 54: 3290-3296.

92. Li B, Kennedy JF, Peng JL, Yie X, Xie BJ (2006) Preparation and performance evaluation of glucomannan-chitosan-nisin ternary antimicrobial blend film Carbohydrate Polymers 65: 488-494.

93. Mathew S, Abraham TE (2008) Characterisation of ferulic acid incorporated starch-chitosan blend films. Food Hydrocolloids 22: $826-835$.

94. Pranoto Y, Rakshit SK, Salokhe VM (2005) Enhancing antimicrobial activity of chitosan films by incorporating garlic oil, potassium sorbate and nisin. LWT-Food Science and Technology 38: 859-865.

95. Li Z, Zhuang XP, Liu XF, Guan YL, Yao KD (2002) Study on antibacterial O-carboxymethylated chitosan/cellulose blend film from $\mathrm{LiCl} / \mathrm{N}, \mathrm{N}$ dimethylacetamide solution. Polymer 43: 1541-1547.

96. Jianglian D, Zhang S (2013) Application of Chitosan Based Coating in Fruit and Vegetable Preservation: A Review. J Food Process Technol 4: $1-4$. 
Citation: Radhakrishnan Y, Gopal G, Lakshmanan CC, Nandakumar KS (2015) Chitosan Nanoparticles for Generating Novel Systems for Better Applications: A Review. J Mol Genet Med S4: 005. doi:10.4172/1747-0862.S4-005

Page 10 of 10

97. Lu Y, Weng L, Zhang L (2004) Morphology and properties of soy protein isolate thermoplastics reinforced with chitin whiskers. Biomacromolecules 5: 1046-1051.

98. Sriupayo J, Supaphol P, Blackwell J, Rujiravanit R (2005) Preparation and characterization of a-chitin whisker-reinforced chitosan nanocomposite films with or without heat treatment. Carbohydrate Polymers 62: 130-136.

99. Sorrentino A, Gorrasi G, Vittoria V (2007) Potential perspectives of bionanocomposites for food packaging applications. Trends in Food Science \& Technology 18: 84-95.

100. López-León T, Carvalho EL, Seijo B, Ortega-Vinuesa JL, Bastos-González D (2005) Physicochemical characterization of chitosan nanoparticles: electrokinetic and stability behavior. J Colloid Interface Sci 283: 344-351.

101. de Moura MR, Avena-Bustillos RJ, McHugh TH, Krochta JM, Mattoso LH (2008) Properties of novel hydroxypropyl methylcellulose films containing chitosan nanoparticles. J Food Sci 73: N31-37.

102. Alexandre M, Dubois P (2000) Polymer-layered silicate nanocomposites: preparation, properties and uses of a new class of materials. Mater Sci Eng R Reports 28: 1-63

103. Averous L, Boquillon N (2004) Biocomposites based on plasticized starch: thermal and mechanical behaviours. Carbohydr Polym 56: 111-122.

104. Mohanty AK, Misra M, Drzal LT (2001) Surface modifications of natural fibres: opportunities and challenges in the green materials world. J Polym Environ 10: 19-26

105. Wollerdorfer M, Bader H (1998) Influence of natural fibres on the mechanical properties of biodegradable polymers. Ind Crops Prod 8: 105-112.

106. Gecol H, Ergican E, Miakatsindila P (2005) Biosorbent for tungsten species removal from water: effects of co-occurring inorganic species. J Colloid Interface Sci 292: 344-353.

107. Caner C, Cansiz O (2007) Effectiveness of chitosan-based coating in improving shelf-life of eggs. Journal of Science of Food and Agriculture 87: $227-232$.

108. Shahidi F, Arachchi JKV, Jeon YJ (1999) Food applications of chitin and chitosans. Trends Food Res Technol 10: 37-51.

109. Vartiainen J, Motion R, Kulonen K, Rättö M, Skyttä E, Ahvenainen R (2004) Chitosan-coated paper: Effects of nisin and different acids on the antimicrobial activity. Journal of Applied Polymer Science 94: 986-993.

110. Mura S, Corrias F, Stara G, Piccinini M, Secchi N, et al. (2011) Innovative composite films of chitosan, methylcellulose, and nanoparticles. J Food Sci 76: N54-60.

111. de Moura MR, Lorevice MV, Mattoso LH, Zucolotto V (2011) Highly stable, edible cellulose films incorporating chitosan nanoparticles. J Food Sci 76: N25-29.

112. Inta O, Yoksan R, Limtrakul J (2014) Hydrophobically modified chitosan: a bio-based material for antimicrobial active film. Mater Sci Eng C Mater Biol Appl 42: 569-577.

113. Bordenave N, Grelier S, Coma V (2010) Hydrophobization and antimicrobial activity of chitosan and paper-based packaging material. Biomacromolecules 11: 88-96,

114. Chien PJ, Sheu F, Yang FH (2007) Effects of Edible Chitosan Coating on Quality and Shelf Life of Sliced Mango Fruit. Journal of Food Engineering 78: 225-229.
115. Han C, Zuo J, Wang Q, Xu L, Zhai B, Wang Z, Dong H, Gao L (2014) Effects of chitosan coating on postharvest quality and shelf life of sponge gourd (Luffa cylindrica) during storage. Scientia Horticulturae 166: 1-8.

116. Dong H, Cheng L, Tan J, Zheng K, Jiang Y (2004) Effects of chitosan coating on quality and shelf life of peeled litchi fruit. Journal of Food Engineering 64: 355-358.

117. Qi H, Hu W, Jiang A, Tian M, Li Y (2011) Extending shelf-life of fresh-cut 'Fuji' apples with chitosan-coatings Innovative Food Science \& Emerging Technologies 12: 62-66.

118. Chien PJ, Lin HR, Su MS (2013) Effects of edible micronized chitosan coating on quality and shelf life of sliced papaya. Food and Nutrition Sciences 4: 9-13.

119. Barry-Ryan C, Martin-Diana A, Rico A, Barat J (2009) Orange juices enriched with chitosan: Optimisation for extending the shelf-life. Food Science and Emerging Technologies 10: 590-600.

120. Wang J (2007) Quality and Shelf Life of Mango (Mangifera Indica L. cv. 'Tainong') Coated by Using Chitosan and Polyphenols. Food Science and Technology International 13: 317-322.

121. Gol NB, Patel PR, Ramana Rao TV (2013) Improvement of quality and shelf-life of strawberries with edible coatings enriched with chitosan. Postharvest Biology and Technology 85: 185-195.

122. Eissa HAA (2008)Effect of chitosan coating on shelf-life and quality of fresh-cut mushroom. Pol J Food Nutr Sci 58: 95-105.

123. Pushkala R, Parvathy KR, Srividya N (2012) Chitosan powder coating, a novel simple technique for enhancement of shelf life quality of carrot shreds stored in macro perforated LDPE packs. Innovative Food Science \& Emerging Technologies 16: 11-20.

124. Shiri MA, Bakhshi D, Ghasemnezhad M, Dadi M, Papachatzis A, Kalorizou H (2013) Chitosan coating improves the shelf life and postharvest quality of table grape (Vitis vinifera) cultivar Shahroudi. Turk J Agric For 37: 148-156.

125. Altieri C, Scrocco C, Sinigaglia M, Del Nobile MA (2005) Use of chitosan to prolong mozzarella cheese shelf life. J Dairy Sci 88: 2683-2688.

126. Bhale S, No HK, Prinyawiwatkul W, Farr AJ, Nadarajah K, Meyers SP (2003) Chitosan coating improves shelf life of eggs. J of Food Science 68: 2378-2383.

127. Bostan K, Isinmahan F (2011) Microbiological quality and shelf-life of Sausage treated with chitosan. J Fac Vet Med Istanbul Üniv 37: 117-126.

128. Souza BW, Cerqueira MA, Ruiz HA, Martins JT, Casariego A, et al. (2010) Effect of chitosan-based coatings on the shelf life of salmon (Salmo salar). J Agric Food Chem 58: 11456-11462.

129. Chamanara V, Shabanpour B, Khomeiri M, Gorgin S (2013) Shelf-life extension of fish samples by using enriched chitosan coating with thyme essential oil. J of Aquatic Food Product Technology 22: 3-10.

130. Ramezani Z, Zarei M, Raminnejad N (2015) Comparing the effectiveness of chitosan and nanochitosan coatings on the quality of refrigerated silver carp fillets. Food Control 51: 43-48. 